\title{
PENINGKATAN KEMAMPUAN REPRESENTASI MATEMATIKA SISWA SMA TUNAS PELITA BINJAI MELALUI PEMBELAJARAN KOOPERATIF BERBASIS MULTIPLE INTELLIGENCE
}

\author{
Suwanto $^{1}$, Fitry Wahyuni ${ }^{2}$ \\ ${ }^{1,2}$ Prodi Pendidikan Matematika STKIP Pelita Bangsa Binjai \\ ${ }^{1}$ suwantompd89@gmail.com, ${ }^{2}$ wahyunifitry17@gmail.com
}

\begin{abstract}
This research aims to determine the increase mathematical representation ability of students with cooperative learning base multiple intelligence. The lower mathematical representation ability and the difficulty in understanding trigonometry and also not facing multiple intelligences is the reason for this research. This research is a quasi experiment that compares two classes with different treatments, cooperative learning based on multiple intelligence and exspositori learning. Learning media in reasech is the RPP and LAS that is validated the expert team. The research instrument was also validated by an expert team and continued with validation, reliability, difficulty and differentiation tests. The analysis used is one-way ANOVA obtained by $F_{\text {count }}(4,342)>F_{\text {table }}(0,05)(4,026)$ Explained, $H_{0}$ is accepted, and it can be concluded that the increased ability of mathematical representation in multiple intelligence-based cooperative learning rather than increasing mathematical representation ability in ordinary learning.
\end{abstract}

Keywords: mathematical representation, cooperative learning, multiple intelligence

\begin{abstract}
Abstrak. Penelitian ini bertujuan untuk mengetahui peningkatan kemampuan representasi matematik siswa dengan menerapkan pembelajaran kooperatif berbasis multiple intelligence. Rendahnya kemampuan representasi matematik siswa dan sulitnya memahami trigonometri serta tidak diperhatikan kecerdasan majemuk (multiple intelligence) merupakan alasannya penelitian ini dilakukan. Jenis penelitian ini adalah eksperimen semu (quasi experiment) yang membandingkan dua kelas eksperimen dengan perlakuan yang berbeda, perlakuan tersebut ialah pembelajaran kooperatif berbasis multiple intelligence dan pembelajaran biasa. Perangkat pembelajaran dalam hal ini RPP dan LAS sebelum digunakan dalam penelitian dilakukan validasi terhadap tim ahli. Instrumen penelitian juga divalidasi oleh tim ahli dan dilanjutkan dengan uji coba untuk mengetahui tingkat validasi, reliabilitas, tingkat kesukaran dan daya pembeda. Analisis yang digunakan adalah Anava satu jalur diperoleh $F_{\text {hitung }}(4,342)>F_{\text {tabel }(0,05)}$ $(4,026)$ sehingga $\mathrm{H}_{0}$ diterim, sehingga dapat disimpulkan bahwa peningkatan kemampuan representasi matematik pada pembelajaran kooperatif berbasis multiple intelligence daripada peningkatan kemampuan representasi matematik pada pembelajaran biasa.
\end{abstract}

Kata kunci : representasi matematik, pembelajaran kooperatif, multiple intelligence

\section{PENDAHULUAN}

Kemampuan representasi matematik merupakan salah satu dari 5 kemampuan yang telah ditetap oleh NCTM. Kemampuan representasi adalah suatu alat atau bentuk yang digunakan untuk mewakili suatu situasi atau masalah agar dapat memecah masalah. Seperti yang diutarakan oleh Brenner (Murni, 2011:97) bahwa Keberhasilan pemecahan masalah bergantung kepada: (1) keterampilan merepresentasi masalah seperti mengkonstruksi dan menggunakan representasi matematik dalam bentuk kata-kata, grafik, tabel, dan persamaan-persamaan; (2) menyelesaikan masalah; dan (3) memanipulasi simbol. Panasuk (2011:33) menyatakan bahwa

"learning how to solve problems that involves linear relationships with one unknown, in a variety of representational modes, is the foundation for developing students' algebraic reasoning. Verbal, pictorial, and symbolic representations are commonly used to model mathematical concepts, in general and for linear relationships with one unknown, in particular." 
Berdasarkan pernyataan di atas kemampuan representasi sangat perlu untuk membantu individu untuk menyelesaikan suatu pemecahan masalah. Yazid (2012:32) menyatakan Representasi bertujuan mempermudah siswa menyelesaikan masalah matematika yang sifatnya abstrak menjadi lebih konkrit bagi siswa. Menurut Abdullah (2012:428) siswa harus memiliki kemampuan representasi dalam mengartikulasikan dan merefleksikan masalah yang sama dengan cara atau pandangan yang berbeda-beda, ke dalam simbol-simbol matematika. Walaupun kemampuan representasi tergolong kemampuan baru dibandingkan dengan empat kemampuan yang ditetapkan oleh NCTM, representasi perlu perhatian yang serius seperti yang dinyatakan Abdullah (2012:429) bahwa representasi merupakan suatu komponen yang layak mendapat perhatian serius. Dengan demikian representasi matematik perlu mendapat penekanan dan dimunculkan dalam proses pengajaran matematika di sekolah. Oleh karena itu di dalam pengajaran matematika, kemampuan mengungkapkan gagasan/ide matematik dan merepresentasikan gagasan/ide matematik dapat merupakan suatu hal yang harus dilalui oleh setiap orang yang sedang belajar matematika.

Pentingnya kemampuan representasi matematik siswa, ternyata tidak sejalan dengan fakta dilapangan khususnya di SMA Tunas Pelita Binjai. Setelah melakukan observasi awal dengan memberikan soal kepada salah satu siswa di SMA Tunas Pelita Binjai hasilnya sebagai berikut. Adapun soal yang diberikan kepada siswa tersebut adalah "Diberikan $\triangle \mathrm{ABC}$, dimana $\mathrm{AC}=\mathrm{BC}$ dan $\mathrm{AC}: \mathrm{AB}=1: 1$, jika $\mathrm{D}$ berada di $\mathrm{AB}$ dan $\mathrm{CD} \perp \mathrm{AB}$, maka sin $\angle \mathrm{DBC}$ ?" dan hasil jawaban yang diperoleh seperti pada gambar di bawah ini

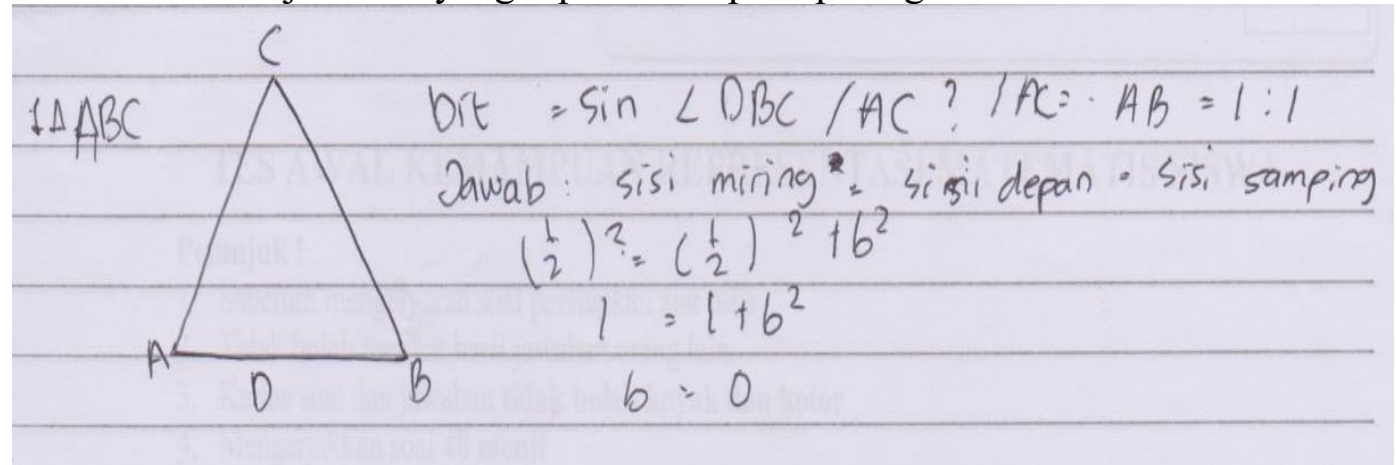

Gambar 1. Hasil Jawaban Representasi Siswa

Jawaban tersebut mencerminkan siswa kurang akurat dalam memrepresentasikan gambar dari soal yang diberikan, kita bisa lihat siswa tersebut tidak mampu mempresentasikan $\mathrm{AC}: \mathrm{AB}=1: 1$ dan tidak dapat merepresentasikan $\mathrm{CD} \perp \mathrm{AB}$. Kemudian dari jawaban siswa tersebut tampak terlihat jelas siswa dalam merepresentasi kalimat "sin $\angle \mathrm{DBC} / \mathrm{AC}$ ?" yang seharusnya direpresentasikan ke dalam "sin $\angle \mathrm{BDC}=\frac{\mathrm{CD}}{\mathrm{BC}}$ ". Selanjutnya siswa juga tidak mampu mempresentasikan teorema phytaogras yang seharusnya " $\mathrm{BC}^{2}=\mathrm{CD}^{2}+\mathrm{BD}^{2}$ " atau " $1^{2}=\mathrm{CD}^{2}+\left(\frac{1}{2}\right)^{2}$ " tetapi siswa tersebut justru menuliskan " $\left(\frac{1}{2}\right)^{2}=\left(\frac{1}{2}\right)^{2}+b^{2}$ ".

Uraian di atas menunjukkan bahwa kemampuan representasi matematik siswa SMA Tunas Pelita Binjai masih rendah. Rendahnya kemampuan representasi matematik siswa tentunya akan berdampak pada hasil belajar matematika siswa. Rendahnya kemampuan representasi matematik siswa bukan terjadi begitu saja tentunya ada sebab dan akibatnya. Salah satu penyebab rendahnya kemampuan representasi matematik siswa adalah metode pembelajaran yang digunakan oleh pengajar atau guru. Sebagaimana diungkapkan oleh Slameto (2010:65) mengungkapkan metode guru yang kurang baik akan mempengaruhi belajar siswa yang tidak baik pula. Metode yang kurang baik itu dapat terjadi misalnya 
karena guru kurang persiapan dan kurang menguasai bahan pelajaran sehingga guru tersebut menyajikannya tidak jelas atau sikap guru terhadap siswa atau terhadap mata pelajaran itu sendiri tidak baik, sehingga siswa kurang senang terhadap pelajaran atau gurunya, akibatnya siswa malas untuk belajar. Turmudi (2008:10) menambahkan bahwa ilmu pengetahuan (matemamtika) yang disampaikan selama ini masih menggunakan sistem trnsmission of knowledge (bagaikan nuangkan air dari poci ke dalam gelas), siswa diperintahkan duduk diam dengan "manis", mendengarkan expository (uraian dan penjelasan) guru.

Rumusan masalah dari penelitian ini adalah apakah peningkatan kemampuan representasi matematik pada pembelajaran kooperatif berbasis multiple intelligence lebih baik daripada peningkatan kemampuan representasi matematik pada pembelajaran biasa.

\section{METODE}

Jenis penelitian ini adalah penelitian eksperimen semu, dikarenakan tidak dapat mengontrol semua variabel yang berkaitan dengan variabel terikat (kemampuan representasi matematik). Tujuan penelitian ini adalah untuk mengetahui peningkatan kemampuan representasi matematik dengan perlakuan pembelajaran kooperatif berbasis multiple intelligence yang dibandingkan dengan kemampuan representasi matematik siswa dengan perlakuan pembelajaran biasa atau pembelajaran ekspositori.

Penelitian dilakukan di SMA Tunas Pelita Binjai yang terletak di jalan Perintis Kemerdekaan No 116, Kebun Lada Binjai yang dilaksanakan selama lima kali pertemuan efektif pada setiap kelas eksperimen dan kelas pembanding. Submateri yang digunakan dalam penelitian trigonometri perbandingan dan sudut rangkap trigonometri.

Sampel yang digunakan dalam penelitia ini sebanyak dua kelas sampel penelitian ditentukan secara sampling random dari tiga kelas XI. Kedua kelas yang menjadi sampel akan diberi pelakuan yang berbeda yakni dengan pembelajaran kooperatif berbasis multiple intelligence dan pembelajaran ekspositori atau pembelajaran biasa.

Instrumen yang digunakan diantaranya; (1) instrumen tes kemampuan representasi matematik untuk mengukur kemampuan representasi matematik dengan tingkat keakurasian atau tingkat reliabel 0,905 ; (2) lembar observasi pembelajaran yang digunakan untuk mengontrol persentase ketepatan kegiatan pembelajaran sesuai dengan RPP yang telah di desain dengan skala Likert. Uji hipotesis yang digunakan dalam penelitian ini adalah analisis satu variabel (anova satu jalur). Data yang akan dianalisis adalah gain atau peningkatan kemampuan represntasi matematik dari masing-masing kelas dengan formula gain (Bao, 2006:917)

$$
\mathrm{g}=\frac{\text { skor postes }- \text { skor pretes }}{\text { skor maksimal ideal }- \text { skor pretes }}
$$

Dengan kriteria tingkat gain sebagai berikut (Ariesta, 201164):

$$
g \leq 0,3 \text { : Rendah }
$$

$$
\begin{array}{r}
0,3<g \leq 0,7: \text { Sedang } \\
0,7<g: \text { Tinggi }
\end{array}
$$




\section{HASIL DAN PEMBAHASAN \\ Hasil}

Setelah diberikan perlakuan yang berbeda dan diberikan tes awal dan tes akhir diperoleh seperti diagram di bawah ini.

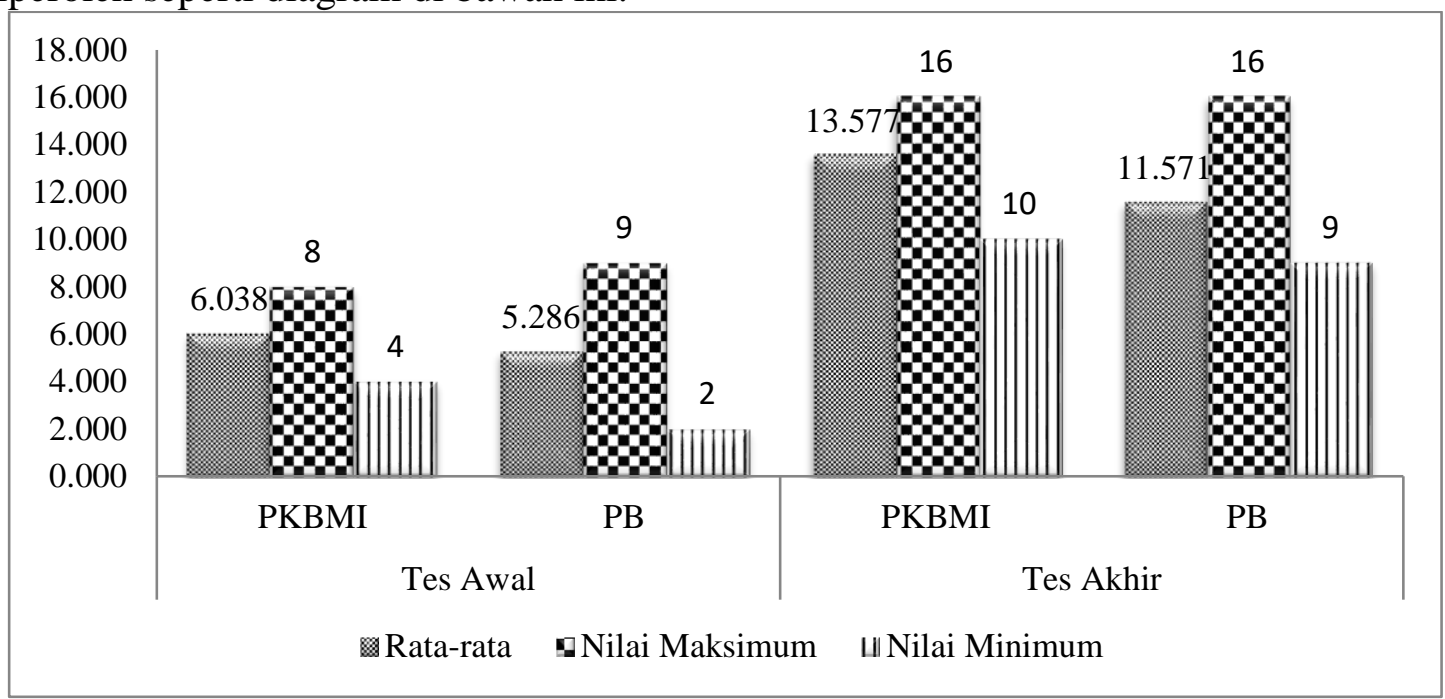

Gambar 2. Diagram Representasi Matematik Pada Tes Awal Dan Tes Akhir

Pada data di atas, terlihat pada tes awal rata-rata kemampuan representasi pada PKBMI $(6,038)$ lebih tinggi daripada rata-rata kemampuan representasi pada kelas PB $(5,28)$, tetapi walaupun demikian nilai maksimum pada PKBMI lebih rendah daripada nilai maksimun pada PB. Dari data tes awal dan tes akhir ditentukan gain kemampuan representasi matematik untuk materi trigonometri, dan diperoleh seperti di bawah ini.

Tabel 1. Gain Kemampuan Representasi Matematik pada PKBMI dan PB

\begin{tabular}{clcc}
\hline No & \multicolumn{1}{c}{ Statistik } & Kelas PKBMI & Kelas PB \\
\hline 1 & Jumlah Data $\left(\sum x_{i}\right)$ & 14,062 & 13,316 \\
\hline 2 & Rerata $(\bar{x})$ & 0,541 & 0,476 \\
\hline 3 & Banyak Siswa $(n)$ & 26 & 28 \\
\hline 4 & Nilai Maksimum $\left(x_{\max }\right)^{*}$ & 0,714 & 0,714 \\
\hline 5 & Nilai Minimum $\left(x_{\min }\right)^{*}$ & 0,286 & 0,182 \\
\hline
\end{tabular}

Berdasarkan data gain di atas dilakukan beberapa uji prasyarat seperti uji normalitas dan uji homogenitas, dengan bantuan SPSS hasil uji normalitas dan homogenitas seperti pada tabel di bawah ini.

Tabel 2. Output Uji Normalitas Data Gain PKMI dan PB

Tests of Normality

\begin{tabular}{|c|c|c|c|c|c|c|c|}
\hline & \multirow{2}{*}{$\begin{array}{l}\text { Pembelaj } \\
\text { aran }\end{array}$} & \multicolumn{3}{|c|}{ Kolmogorov-Smirnov ${ }^{a}$} & \multicolumn{3}{|c|}{ Shapiro-Wilk } \\
\hline & & Statistic & Df & Sig. & Statistic & Df & Sig. \\
\hline \multirow[t]{2}{*}{ Gain } & PKBMI & .136 & 26 & $.200^{*}$ & .942 & 26 & .148 \\
\hline & PB & .164 & 28 & .053 & .952 & 28 & .216 \\
\hline
\end{tabular}

a. Lilliefors Significance Correction

${ }^{*}$. This is a lower bound of the true significance.

Uji hipotesis untuk normalitas adalah sebagai berikut

$\mathrm{H}_{\mathrm{o}}=$ data berasal dari populasi yang berdistribusi normal

$\mathrm{H}_{\mathrm{a}}=$ data berasal dari populasi tidak berdistribusi normal

Dengan kriteria pengujian jika $x_{\text {hitung }}^{2}<x_{\text {tabel }}^{2}$ atau significance (sig.) $>0,05$ maka $\mathrm{H}_{\mathrm{o}}$ diterima, sebaliknya jika $x^{2}$ hitung $>x_{\text {tabel }}^{2}$ atau significance $($ sig. $)<0,05$ maka $\mathrm{H}_{\mathrm{o}}$ ditolak atau 
$\mathrm{H}_{\mathrm{a}}$ diterima. Karena nilai signifikan (sig.) $>0,05$, maka $\mathrm{H}_{0}$ diterima dengan demikian data gain kemampuan representasi matematik berasal dari data yang berdistribusi normal.

Tabel 3. Hasil Output Uji Homogenitas

Test of Homogeneity of Variance

\begin{tabular}{llrrrr}
\hline & Levene Statistic & df1 & df2 & Sig. \\
\hline Gain & Based on Mean & 2.639 & 1 & 52 & .110 \\
& Based on Median & 1.998 & 1 & 52 & .163 \\
& $\begin{array}{l}\text { Based on Median and with } \\
\text { adjusted df }\end{array}$ & 1.998 & 1 & 51.603 & .164 \\
$\quad$ Based on trimmed mean & 2.563 & 1 & 52 & .115 \\
\hline
\end{tabular}

Uji hipotesis untuk uji homogenitas yang digunakan adalah

Ha $: \sigma_{1}^{2}=\sigma_{2}^{2}$ : Variansi pada tiap kelompok data tidak sama (tidak homogen)

$\mathrm{H}_{\mathrm{o}}: \sigma_{1}^{2} \neq \sigma 22$ :Variansi pada tiap Kelompok data sama (homogen)

Kriteria pengujian yang digunakan adalah $\mathrm{H}_{\mathrm{a}}$ diterima dan $\mathrm{H}_{\mathrm{o}}$ ditolak jika nilai sig < 0,05 dan $\mathrm{H}_{\mathrm{o}}$ diterima dan $\mathrm{H}_{\mathrm{a}}$ ditolak jika nilai sig. $>0,05$. Pada hasil output di atas diperoleh nilai sig. $(0,11)<0,05$ dengan demikian $\mathrm{H}_{\mathrm{o}}$ diterima dan $\mathrm{H}_{\mathrm{a}}$ ditolak atau dengan kata lain kedua varians berasal dari data yang homogen.

Setelah uji prasyarat dilkukan dan memenuhi syarat kehomogenitas, maka dapat dilakukan analisis varians satu jalur yang dikenal dengan Anova One Way. Hasil output dengan SPSS maka diperoleh seperti di bawah ini.

Tabel 4. Hasil Output Anova Satu Jalur

ANOVA

\begin{tabular}{lrrrrr}
\cline { 2 - 5 } Gain & \multicolumn{1}{c}{} & & \\
\hline & Sum of Squares & Df & Mean Square & F & Sig. \\
\hline Between Groups & .057 & 1 & .057 & 4.342 & .042 \\
Within Groups & .686 & 52 & .013 & & \\
Total & .743 & 53 & & &
\end{tabular}

Pada uji anova dengan SPSS kriteria kesimpulan Ha : diterima jika sig $<0,05$ dan $\mathrm{H}_{\mathrm{o}}$ diterima jka nilai sig. $>0,05$. Karena nilai sig. $(0,42)<0,05$ maka $\mathrm{H}_{\mathrm{a}}$ diterima atau dengan kata lain peningkatan (gain) pada kemampuan representasi matematik siswa berbeda atau peningkatan kemampuan representasi matematik siswa pada pembelajaran siswa lebih baik dari pada peningkatan kemampuan representasi matematik pada pembelajaran biasa.

\section{Pembahasan}

Pada penelitian ini hipotesis yang diajukan ialah apakah peningkatan representasi matematik siswa yang diajarkan dengan pembelajaran kooperatif berbasis multiple intelligence lebih baik daripada peningkatan kemampuan representasi matematik siswa dengan pembelajaran biasa atau pembelajaran ekspositori. Berdasarkan hasil analisis varians baik secara manual dan menggunakan SPSS 16 menunjukkan hasil yang sama yakni $\mathrm{H}_{0}$ diterima dengan demikian dapat disimpulkan bawah peningkatan kemampuan representasi matematik dengan PKBMI lebih baik daripada peningkatan kemampuan representasi matematik dengan $\mathrm{PB}$.

Hasil uji statistik di atas tidak sesuatu yang kebetulan semata, beberapa teori juga mendukung akan hal tersebut. Jika di lihat dari beberapa indikator dari kemampuan representasi seperti mengilustrasikan, menyatakan dan mengekspresikan dalam matematik, maka seperti terdapat keterkaitan yang signifikan antara kemampuan representasi matematik dengan pembelajaran kooperatif berbasis multiple inttelligence. Soal-soal trigonometri yang sengaja didisain bagaimana mempresentasikan masalah ke dalam 
gambar atau model matematika, dimana tentunya secara tidak langsung kegiatan belajar ini akan berkaitan langsung dengan kecerdasan spasial mereka.

Bukan hanya kecerdasan spasial, kecerdasan yang lain juga ikut terlibat pada setiap pembelajaran walaupun peran kecerdasan berbeda-beda setiap pertemuan. Misalkan saja pada pertemuan kedua dimana mereka mengkombinasikan sebuah angka-angka menjadi sebuah not lagu yang akan dimainkan mereka ditebak mereka irama lagunya. Para siswa antusias mencoba menjawab soal, menemukan kombinasi angka dan memainkan irama bilangannya. Dampakanya kecerdasan kinestetik mereka terlalu over berlebihan dan kelas tampak gaduh saat dilakukan pembelajaran. Walaupun demikian mereka merasakan sensasi yang berbeda saat belajar matematika, ketertarikkan terhadap matematika mencerminkan bahwa mereka termotivasi dalam belajar matematika, Hamdu (2011) mottivasi belajar siswa mempengaruhi hasil belajar siswa. Kemudian mereka mencoba melakukan instruksi dari soal menggambar, mengilustrasikan soal atau mempresentasikan soal. Slameto (2010:36) aktivitas siswa dapat menjalankan perintah, melaksanakan tugas, membuat grafik, diagram, inti sari dari pelajaran yang disajikan oleh guru. Jika siswa menjadi partisi aktif maka ia akan dapat memiliki ilmu/pengetahuan itu dengan baik.

\section{KESIMPULAN DAN SARAN \\ Kesimpulan}

Berdasarkan hasil penelitian dan pembahasan penelitian pada bab sebelumnya, maka dapat di simpulkan bahwa peningkatan kemampuan representasi matematik siswa dengan pembelajaran kooperatif berbasis multiple inttelligence lebih baik daripada peningkatan kemampuan representasi matematik siswa dengan pembelajaran biasa atau pembelajaran ekspositori

\section{Saran}

Beberapa saran yang dapat disampaikan oleh penulis diantaranya:

1. Bagi para guru matematika saat menggunakan model pembelajaran ini, hendaknya mempertimbangan materi, waktu dan kecerdasan majemuk yang terlibat saat proses belajar mengajar berlangsung.

2. Bagi peneliti selanjutnya hendaknya melakukan berapa tindakan penelitian untuk mendapatkan hasil yang akurat dengan tujuan penelitian mengenai peningkatan kemampuan representasi matematik siswa.

3. Bagi lembaga terkait diharapkan dapat mensosialisasikan pembelajaran kooperatif berbasis multiple intelligence untuk meningkatkan kemampuan representasi matematik pada jenjang SMA.

\section{DAFTAR PUSTAKA}

Abdullah, I. H. 2012. Peningkatan Kemampuan Representasi Matematik Siswa SMP Melalui Pembelajaran Kontekstual yang Terintegrasi dengan Soft Skill. FKIP UNY, Yogyakarta: Prosiding. ISBN:978-979-16353-8-7. Hal 427-436

Ariesta, R. 2011. Pengembangan Perangkat Perkuliahan Kegiatan Labratorium Fisika Dasar II Berbasis Inkuiri Terbimbing Untuk Meningkatkan Kerja Ilmiah Mahasiswa. UNNES: Jurnal Pendidikan Fisika Indonesia.

Bao, L. 2006. Theoretical Comparisons of Average Normalize Gain Calculation. Physics Education Research. 74(10).

Hamdu, G. 2011. Pengaruh Motivasi Belajar Siswa terhadap Prestasi Belajar Siswa di Sekolah Dasar. Jurnal Penelitian Pendidikan, 12(1).

Murni, A. 2011. Peningkatan Kemampuan Representasi matematik Siswa SMP Melalui Pembelajaran Metakognitif dan Pembelajaran Metakognitif Berbasis Soft Skill. FKIP Universitas Riau 
Panasuk, R M. 2011. Preferred Representations of Middle School Algebra Students When Solving Problems. University of Massachusetts Lowell, USA: The Mathematics Educator, 13(1), Hal. 32-52.

Slameto. 2010. Belajar dan Faktor-Faktor yang Mempengaruhi. Jakarta: Rineka Cipta

Turmudi. 2008. Landasan Filsafat dan Teori Pembelajaran Matematika.Jakarta: Leuser Cita Pustaka.

Yazid, A. 2012. Pengembangan Perangkat Pembelajaran Matematika Model Kooperatif dengan Strategi TTW (Think-Talk-Write) pada Materi Volume Bangun Ruang Sisi Datar. Journal of Primary Education, 1(1). 